\title{
STRONG POROUS GLASS-CERAMICS FROM ALKALI ACTIVATION AND SINTER-CRYSTALLIZATION OF VITRIFIED MSWI BOTTOM ASH
}

\author{
Patricia Rabelo Monich ${ }^{1}$, Fulden Dogrul ${ }^{1,2}$, Hugo Lucas ${ }^{3}$, Bernd Friedrich ${ }^{3}$ and Enrico \\ Bernardo $1, *$
}

${ }^{1}$ Department of Industrial Engineering, University of Padova, 35131 Padova, Italy

${ }^{2}$ Department of Metallurgy and Materials Engineering, Sakarya University, 54187 Sakarya, Turkey

${ }^{3}$ IME Process Metallurgy and Metal Recycling, RWTH Aachen University, 52056 Aachen, Germany

Article Info:
Received:
17 April 2019
Revised:
11 July 2019
Accepted:
23 July 2019
Available online:
23 December 2019
Keywords:
Vitrified bottom ash
Porous glass-ceramics
Waste derived glasses
Alkali activation
Gel-casting
Upcycling

Received:

17 April 2019

Revised:

23 December 2019

Vitrified bottom ash

Porous glass-ceramics

Alkali activation

Upcycling

\begin{abstract}
Vitrification of municipal solid waste incineration (MSWI) bottom ash is an effective method to produce a chemically stable glass, with metal recovery. In order to justify the high costs of this process, the vitrified residue can then be upcycled into potential marketable products. In this study, vitrified bottom ash was successfully converted into strong and chemically stable porous glass-ceramics by the combination of alkali activation and sintering. After the activation of the glass in a $\mathrm{NaOH}$ solution of low molarity, foams were easily produced by intensive mechanical stirring, with the aid of a surfactant, and stabilized by gelation. The obtained open-celled material was further consolidated by a sintering treatment, at $800-900^{\circ} \mathrm{C}$. The addition of recycled soda-lime glass allowed activation at low molarity and sintering at lower temperature, but it reduced the mechanical properties and the stabilization of heavy metals. On the other hand, the increase in molarity of the alkaline solution increased the porosity and also the strength of foams from vitrified bottom ash.
\end{abstract}

\section{INTRODUCTION}

The quantity of municipal solid waste (MSW) produced has never been higher. It has been estimated that around 1.3 billion tonnes of solid waste were produced in the world in 2012, which may dramatically increase to 2.2 billion tonnes by 2025 (Hoornweg \& Bhada-Tata, 2012). In the EU 28, almost $30 \%$ of MSW produced is still being landfilled, with significantly different rates among the European countries (Cucchiella, D’Adamo, \& Gastaldi, 2017). An alternative to landfilling of MSW is represented by incineration with energy recovery, in which up to 90 vol\% of waste can be reduced (Tillman, Vick, \& Rossi, 1989). Besides the exhaust gas (which is used to generate energy), municipal incinerators produce two types of residues, fly ash and bottom ash. Bottom ash represents more than $98 \%$ of the incineration outputs (Joseph, Snellings, Van den Heede, Matthys, \& De Belie, 2018) and it is currently treated mechanically using screeners, crushers, magnets, eddy current separators, sorting technologies and washers to extract the metallic fraction and clean as maximum as possible the mineral fraction. In the EU, the rest of bottom ash is mostly landfilled, but in some other instances it can be used as aggregate for road paving or construction (Sabbas et al., 2003).
In addition, previous studies reported that the treated bottom ash can also be valorised into new products such as tiles, bricks and alkali activated materials (R. V. Silva, de Brito, Lynn, \& Dhir, 2017). However, as this residue can still contain hazardous metals, chlorides, sulphates and other pollutants, it is crucial to perform an environmental impact assessment of the developed material before its commercialization (R. V. Silva, de Brito, Lynn, \& Dhir, 2019). In fact, environmental issues that can be caused by bottom ash lies as one of the main reasons why this ash is still being mainly landfilled (He, Pu, Shao, \& Zhang, 2017). Another option of managing the bottom ash is through the vitrification of the residue, which generates a chemically stable and homogeneous glass (Bassani et al., 2009). However, as vitrification is an high demanding energy process, it is only economically viable if the glass can then be upcycled into high added value products, such as glass-ceramics (Colombo, Brusatin, Bernardo, \& Scarinci, 2003).

Upcycling of vitrified residues into marketable products has been extensively referred to in the literature. Examples include tiles, aggregates for reinforcement of concrete and glass foams for thermal and acoustic insulation (Rincón, Marangoni, Cetin, \& Bernardo, 2016). The latter can offer 
a series of interesting properties for building construction such as low density, high compressive strength, flame resistance and nontoxicity (Rincón et al., 2016; Scarinci, Brusatin, \& Bernardo, 2006). Unlike the extensively used polymeric foams, glass foams consist in a much safer option for building insulation in case of fire. However, these foams are still quite expensive to be produced due to specific process and additives used (Monich, Romero, Höllen, \& Bernardo, 2018).

An alternative technique, aimed at decreasing the high cost involved in the production of glass foams and based on alkali activation, has been recently developed (Rincón, Giacomello, Pasetto, \& Bernardo, 2017). According to this approach, that could be defined of 'inorganic gel casting', a suspension of fine glass powders, in an alkaline solution of low molarity, undergoes progressive hardening due to the formation of surface gels (Elsayed et al., 2017; GarciaLodeiro, Aparicio-Rebollo, Fernández-Jimenez, \& Palomo, 2016; Monich et al., 2018; Rincón et al., 2017), in turn due to the partial dissolution of the same glass. Before complete setting, a surfactant is added to the suspension, later subjected to intensive mechanical stirring. The trapping of air bubbles, favoured by the surfactant, determines a substantial foaming. When stirring is ceased, the ongoing gelation prevents the collapse of the foamed 'green' structure. The material is then extracted from the container, dried and sintered by viscous flow (Rincón et al., 2017). This technique has already been successfully applied in the production of highly porous and strong waste derived materials (Monich et al., 2018; Rincón, Desideri, \& Bernardo, 2018; Rincón et al., 2017; Rincon Romero, Salvo, \& Bernardo, 2018) as well as bioactive glass-ceramics (Elsayed et al., 2017).

In this study, the process of alkali activation, gelation and sintering was extended to produce porous glass-ceramics made with vitrified bottom ash (VBA). This glass residue was obtained from the smelting of bottom ash by using an electric arc furnace, followed by quenching. Electric arc furnace is a simple built technology with low thermal losses and high output, frequently employed in the vitrification of residues (Colombo et al., 2003). Four different types of porous glass-ceramics were developed in order to minimize costs of production, especially related to the alkaline solution and heating treatment, without compromising the mechanical properties and chemical stability of the foams. Recycled soda-lime glass (SLG) was used to aid the gelation and sintering process of two groups of materials (Monich et al., 2018).

The overall approach does not strictly match with the concept of 'landfill mining' (Monich et al., 2018), according to which landfill remediation is performed by excavation, removal of directly recyclable components (e.g. metallic objects, plastics), pyrolysis (with transformation of organic compounds into combustible gas) and conditioning of the inorganic residue. It should be noted, however, that the conversion of vitrified bottom ash into glass-ceramics may represent a model for the last operation of landfill mining. Once the inorganic residue is melted, and valuable metals are separated, a full 'circularity' (i.e. "enhanced landfill mining") will be achieved only in the hypothesis of reuse also of the non-metallic fraction.

\section{MATERIALS AND METHODS}

MSWI bottom ash was gently provided by the company AVR (Netherlands) and dried at $200^{\circ} \mathrm{C}$ for $24 \mathrm{~h}$. Thereafter, the dried bottom ash (up to $3 \mathrm{~kg}$ by trial) was added to a graphite crucible and smelted in a lab-scale electric arc furnace operating in $\mathrm{DC}$ at around $1500^{\circ} \mathrm{C}$ for 60 minutes. $\mathrm{A}$ graphite electrode of $50 \mathrm{~mm}$ was used on the top (Figure 1). After the smelting, the melt residue was quenched in water, dried and crushed (by means of a jaw crusher) in order to separate a metal fraction (up to $14 \mathrm{wt} \%$ ). The nonmetallic fraction was dry ball milled, until the particle size was below $75 \mu \mathrm{m}$.

The chemical composition of the obtained vitrified bottom ash (Table 1) was assessed by a PANanalytical WDXRF spectrometer it is quite similar to the one of "slag sitals" (specially concerning amounts of $\mathrm{SiO}_{2}, \mathrm{CaO}, \mathrm{Na}_{2} \mathrm{O}$, $\mathrm{MgO}, \mathrm{Fe}_{2} \mathrm{O}_{3}$ and $\mathrm{Cr}_{2} \mathrm{O}_{3}$ ). "Slag sitals" consisted on strong and chemically stable slag derived glass-ceramics developed in the late USSR (Höland \& Beall, 2012). Table 1 also shows the chemical composition of soda-lime glass which was employed in the development of two groups of porous glass-ceramics. This glass (medium particle size equal to $30 \mu \mathrm{m}$ ) was gently provided by SASIL SpA (Brusnengo, Biella, Italy) after colour selection and removal of metallic and polymeric residues from the glass cullet. This fraction is usually not recycled due to ceramic contaminations (Rincón et al., 2017).

Thermal analysis (DSC/TGA, 3+ STARe System, Mettler Toledo, Columbus, $\mathrm{OH}, \mathrm{USA})$, with heating rate of $10^{\circ} \mathrm{C} / \mathrm{min}$, was done on fine powders (particle size $<75 \mu \mathrm{m}$ ) as well on coarse powder (particle size $\sim 1 \mathrm{~mm}$ ) of vitrified bottom ash in order to determine the physico-chemical transformations occurring during heating.

Porous glass-ceramics were produced by firstly mixing at $400 \mathrm{rpm}$ fine powders of the waste glasses to an alkaline solution of $\mathrm{NaOH}$ for $3 \mathrm{~h}$. The overall solid loading content used was of $70 \mathrm{wt} \%$. After the partial dissolution of the fine powders, 4 wt $\%$ of surfactant (Triton X-100, (polyoxyethylene octyl phenyl ether $-\mathrm{C} 14 \mathrm{H} 22 \mathrm{O}(\mathrm{C} 2 \mathrm{H} 4 \mathrm{O}) \mathrm{n}, \mathrm{n}=9-10$, Sig-

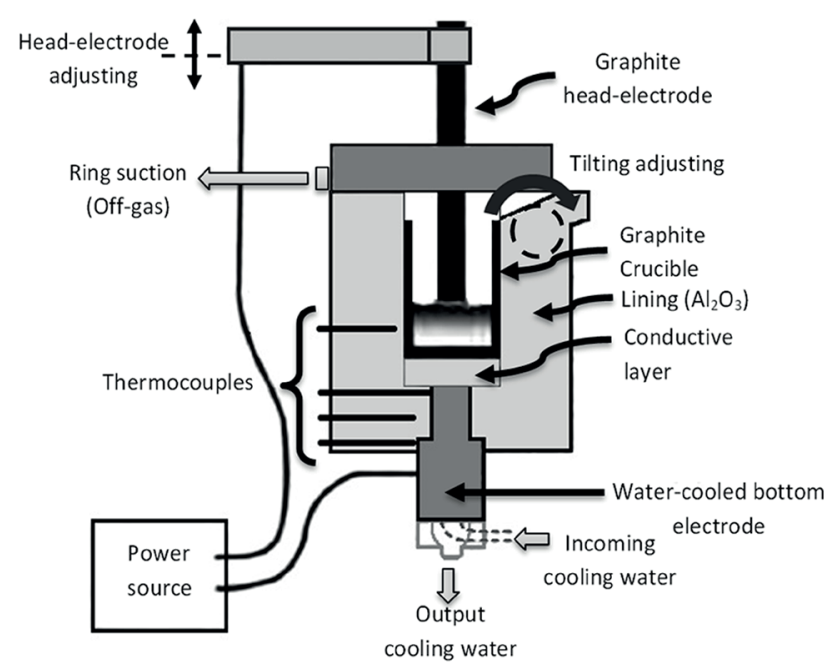

FIGURE 1: Sketch of the lab-scale submerged arc furnace (SAF). 
TABLE 1: Chemical composition of the glasses employed in this study (wt\%)

\begin{tabular}{|c|c|c|}
\hline & Vitrified bottom ash & Soda-lime glass \\
\hline $\mathrm{SiO}_{2}$ & 50.32 & 71.9 \\
\hline $\mathrm{CaO}$ & 20.90 & 7.5 \\
\hline $\mathrm{Al}_{2} \mathrm{O}_{3}$ & 19.03 & 1.2 \\
\hline $\mathrm{Na}_{2} \mathrm{O}$ & 4.59 & 14.3 \\
\hline $\mathrm{MgO}$ & 2.65 & 4 \\
\hline $\mathrm{TiO}_{2}$ & 0.85 & 0.1 \\
\hline $\mathrm{K}_{2} \mathrm{O}$ & 0.75 & 0.4 \\
\hline $\mathrm{CuO}$ & 0.21 & \\
\hline $\mathrm{BaO}$ & 0.18 & \\
\hline $\mathrm{Fe}_{2} \mathrm{O}_{3}$ & 0.14 & 0.3 \\
\hline $\mathrm{MnO}$ & 0.13 & \\
\hline SrO & 0.11 & \\
\hline $\mathrm{ZrO}_{2}$ & 0.06 & \\
\hline $\mathrm{Cr}_{2} \mathrm{O}_{3}$ & 0.05 & \\
\hline $\mathrm{P}_{2} \mathrm{O}_{5}$ & 0.02 & \\
\hline $\mathrm{Cl}$ & 0.02 & \\
\hline
\end{tabular}

ma-Aldrich, Gillingham, UK) was added to the suspension, which was then submitted to an intensive mechanical stirring at $2000 \mathrm{rpm}$. The foamed suspension was subsequently dried at $40^{\circ} \mathrm{C}$ for $48 \mathrm{~h}$, demoulded and fired at $800^{\circ} \mathrm{C}$ or $900^{\circ} \mathrm{C}$, with heating rate of $10^{\circ} \mathrm{C} / \mathrm{min}$ and a holding time of $1 \mathrm{~h}$. Table 2 presents the conditions applied to produce the four different groups of samples.

The mineralogical analysis of crushed fired foams was performed by X-ray diffraction (XRD) (Bruker D8 Advance, Karlsruhe, Germany), using CuKa radiation, $0.15418 \mathrm{~nm}, 40$ $\mathrm{kV}-40 \mathrm{~mA}, 2 \theta=15-60^{\circ}$, step size $0.05^{\circ}, 2$ s counting time. High resolution $X$-ray diffraction analysis was done on fine powders of vitrified bottom ash and on not fired crushed foams. In this case, a position sensitive detector was used, with step size of $0.02^{\circ}$ and counting time of $2 \mathrm{~s}$. This generated a distinctive high signal-to-noise ratio, which allowed to identify the crystalline reaction products of alkali activation. The Match!® program package (Crystal Impact GbR, Bonn, Germany), supported by data from Powder Diffraction File (PDF)-2 database (International Centre for Diffraction Data, Newtown Square, PA, USA) was used for phase identification.

Fourier-transform infrared spectra were collected with Jasco 4200 FTIR spectrometer (Jasco, Japan) equipped with an attenuated total reflection (ATR) attachment (ZnSe

TABLE 2: Approaches applied in the production of samples.

\begin{tabular}{|c|c|c|c|c|}
\hline Group of samples & A & B & C & D \\
\hline $\begin{array}{l}\text { Molarity of the } \\
\text { alkaline solution }\end{array}$ & $1 \mathrm{M}$ & $1.5 \mathrm{M}$ & $1 \mathrm{M}$ & $1 \mathrm{M}$ \\
\hline Composition & $100 \%$ VBA & $100 \%$ VBA & $90 \%$ VBA/ & \\
\hline $10 \%$ SLG & $90 \%$ VBA/ & & & \\
\hline \multicolumn{5}{|l|}{$10 \%$ SLG } \\
\hline Firing temperature & $900^{\circ} \mathrm{C}$ & $900^{\circ} \mathrm{C}$ & $900^{\circ} \mathrm{C}$ & $800^{\circ} \mathrm{C}$ \\
\hline
\end{tabular}

crystal) on the powdered samples of vitrified bottom ash and on the samples from group $B$ before and after sintering. For each measurement 32 scans were coded at a resolution of $4 \mathrm{~cm}^{-1}$, in the range of $700 \mathrm{~cm}^{-1}$ to $4000 \mathrm{~cm}^{-1}$.

The fired foams were cut into cubes (side of approximate $10 \mathrm{~mm}$ ) and used for further characterizations. The bulk density of the fired foams was calculated by the ration of the mass (measured with a digital balance) to the volume (measured by using a caliper) of the samples. A gas pycnometer (Micromeritics AccuPyc 1330, Norcross, GA) was employed to measure the apparent and true densities of the foams and of the finely crushed samples, respectively.

The compressive strength of 10 porous glass-ceramics of each group was determined by using an Instron 1121 UTM (Instron Danvers, MA). The mechanical test was done at room temperature with a cross-head speed of $1 \mathrm{~mm} / \mathrm{min}$.

The morphological and microstructural characterizations of the fired foams was assessed by means of an optical stereomicroscopy (AxioCam ERc 5 s Microscope Camera, Carl Zeiss Microscopy, Thornwood, New York, USA).

The chemical stability of vitrified bottom ash and of each group of fired foams was evaluated by means of leaching test, based on norm EN 12457-4 ("Norm EN 12457-4," 2002). The materials were firstly crushed and sieved below $4 \mathrm{~mm}$. Thereafter, the sieved fragments were added to a plastic flask with pure distilled water (liquid/solid ratio of $10)$, which was submitted to mixing for $24 \mathrm{~h}$ at room temperature. The suspension was then filtered and centrifuged, obtaining the eluate. Inductively coupled plasma mass spectrometry (ICP-OES, Spectro Genesis, Germany) was used to measure the heavy metals of the eluate. The leachate values allowed for waste acceptable at landfills for inert waste and non-hazardous waste (Directive 2003/33/ EC, 2003) was used as a reference.

\section{RESULTS AND DISCUSSION}

The crystallization temperature (Tc) of fine powder of vitrified bottom ash lies around $925^{\circ} \mathrm{C}$, according to the differential scanning calorimetry (DSC) curve of the fine powder of vitrified bottom ash (Figure 2a). This temperature was used as a reference for firing experiments, which were performed at $900^{\circ} \mathrm{C}$. Foams made with addition of soda-lime glass were also fired at $800^{\circ} \mathrm{C}$, in an attempt to decrease energy consumption during sintering. It was not possible to detect the crystallization temperature of the coarse powder, which indicates that this glass is sensitive to surface crystallization (E. Bernardo, 2008). The particle size of the glass did not influence the thermogravimetry analysis (TGA, Figure 2b): the TGA curves show a decrease in mass of less than $0.5 \%$ at higher temperatures, for fine vitrified bottom ash.

The FTIR spectra provided information on the hardening mechanism (Figure 3). Even considering the strongest activation (Figure 3a, B green), the formation of C-S-H compounds, at the basis of the obtainment of glass foams from 'inorganic gel casting' (Rincón et al., 2017), is hardly visible: peaks at $3458 \mathrm{~cm}^{-1}$ and at $1680 \mathrm{~cm}^{-1}$, attributed to $\mathrm{O}-\mathrm{H}$ stretching and $\mathrm{O}-\mathrm{H}$ bending, remained very slight. The main peak at $1450 \mathrm{~cm}^{-1}$, visible in all groups of green foams, cor- 

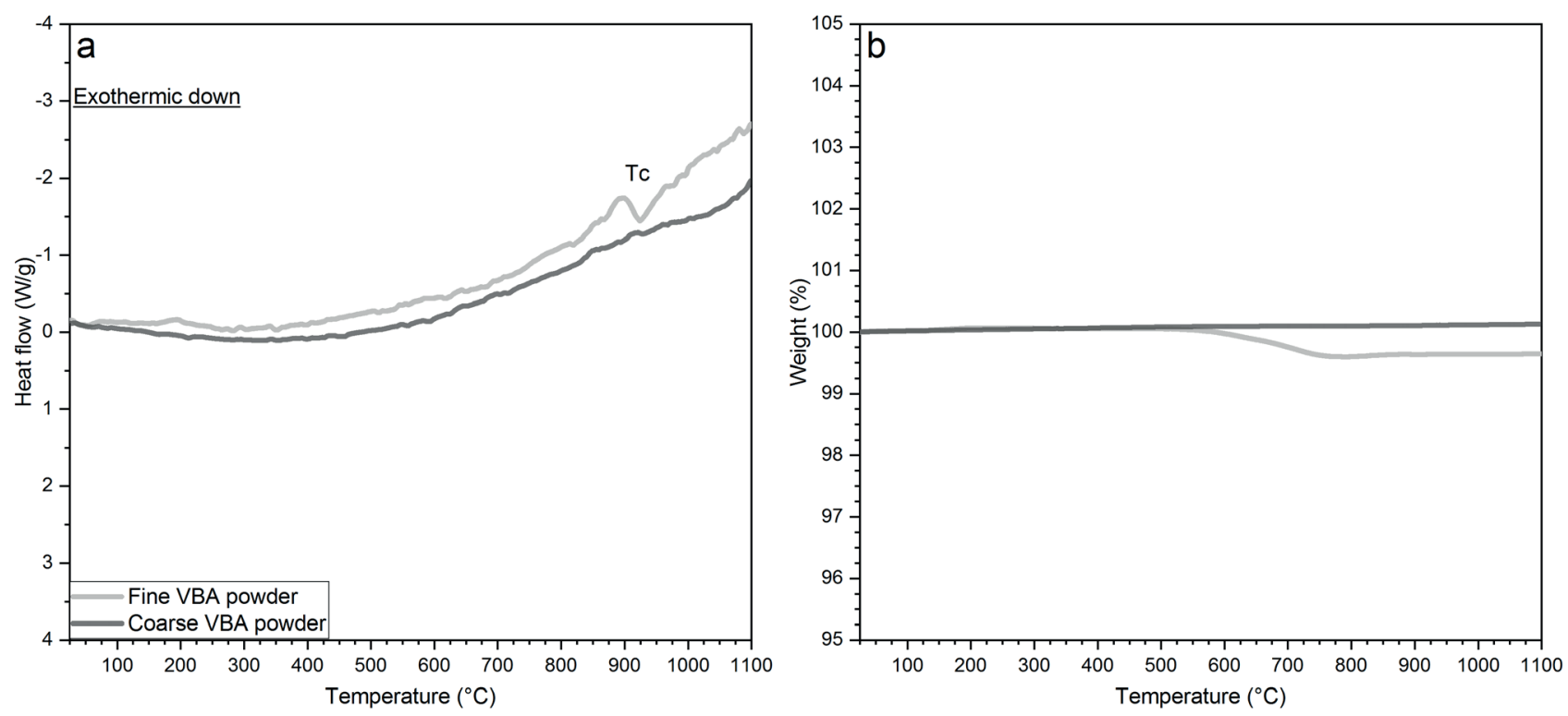

FIGURE 2: DSC (a) and TGA (b) curves of fine and coarse powder of vitrified bottom ash.
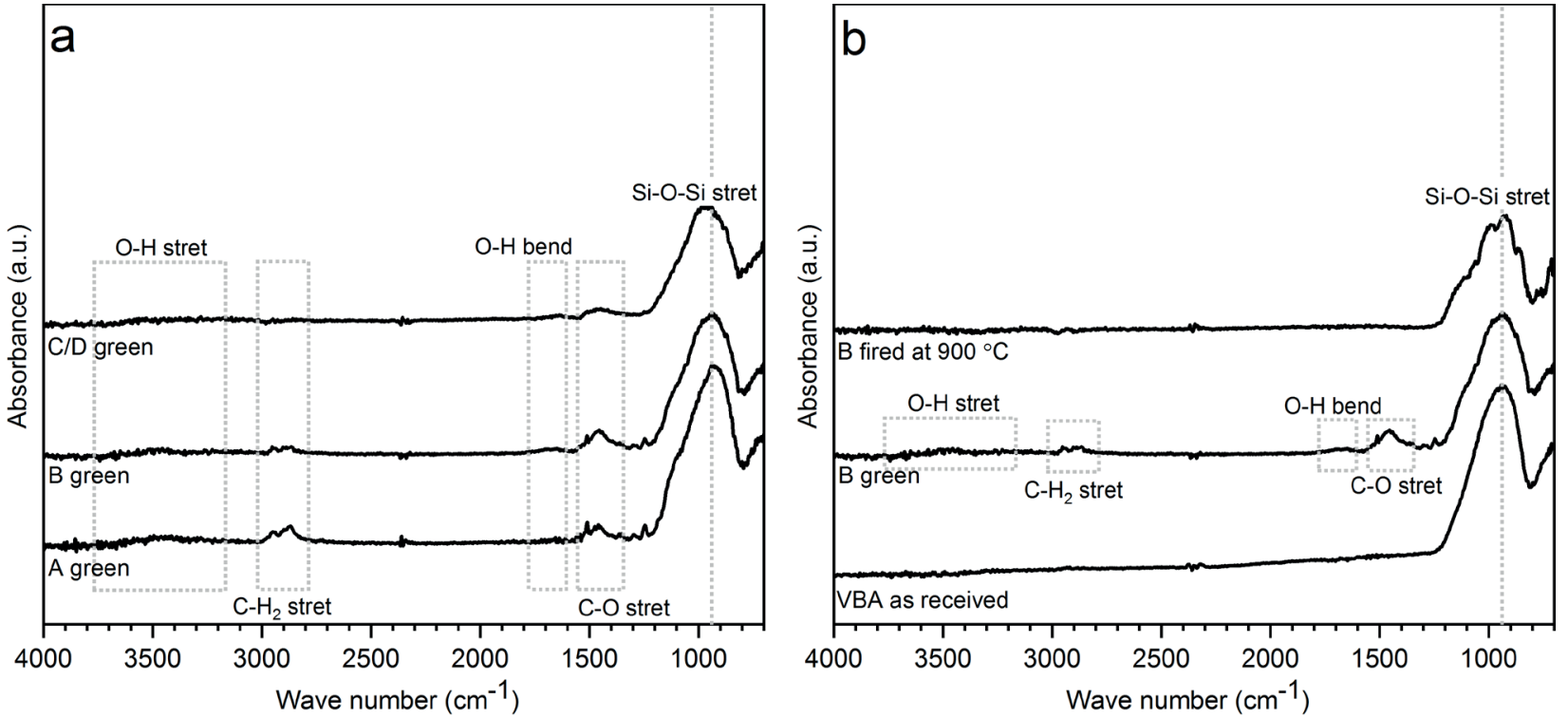

FIGURE 3: FTIR spectra of: a) foams from groups A, B and C/D before firing; b) vitrified bottom ash and foams from group B before and after firing.

responds to the stretching vibration of $\mathrm{C}-\mathrm{O}$ (Rincon Romero et al., 2018). This finding confirms recently reported experiences (Rincon Romero et al., 2018), according to which the hardening of the activated vitrified bottom ash is mainly due to carbonation. Furthermore, the peak at $2900 \mathrm{~cm}^{-1}$ is associated to $\mathrm{C}-\mathrm{H}_{2}$ stretching due to the addition of the surfactant (Monich et al., 2018). Regarding the spectrum of vitrified bottom ash (Figure $3 \mathrm{~b}$ ), the band between 800 $\mathrm{cm}^{-1}$ and $1260 \mathrm{~cm}^{-1}$ corresponds to the asymmetric Si-O-Si stretching vibration (Paola Pisciella \& Pelino, 2005). This bands becomes slightly narrower after alkali activation and it is separated in more peaks after the firing treatment, probably due to crystallization (Rincon Romero et al., 2018).

High resolution X-ray diffraction analysis (Figure 4) allowed to identify which carbonated and hydrated pha- ses were formed, according to alkali activation. Trona $\left(\mathrm{Na}_{3} \mathrm{H}\left(\mathrm{CO}_{3}\right)_{2} \cdot 2\left(\mathrm{H}_{2} \mathrm{O}\right)\right.$, PDF\#00-029-1447) was detected as the only newly formed phases, in green foams (i.e. after foaming and drying) from group $A$, in agreement with previous findings in alkali activated vitrified bottom ash (Rincon Romero et al., 2018), made with a stronger activating solution (2.5 M NaOH).

Unlike in previous experiences, in order to favour the handling of foams upon demoulding (green ' $A$ ' foams were particularly weak), pre-foaming and curing step (aimed at enhancing the dissolution) were not applied. Instead, a slight increase in molarity of activating solution was considered. Passing from $1 \mathrm{M}$ (Figure 4, group A) to $1.5 \mathrm{M}$ (Figure 4 , group $B$ ) favoured the formation of more phases, contributing to the hardening. The $\mathrm{X}$-ray signals are consistent 
with meionite $\left(\left(\mathrm{Ca}_{3} \cdot 4 \mathrm{Na}_{0.64}\right)\left(\mathrm{Al}_{5 \cdot 43} \mathrm{Si}_{659}\right) \mathrm{O}_{24}\left(\mathrm{CO}_{3}\right)_{0.88} \mathrm{O}_{0.12}\right.$ PDF\#75-1222), sodium carbonate ( $\left.\mathrm{Na}_{2} \mathrm{CO}_{3}, \mathrm{PDF} 886-0315\right)$, tilleyite $\left(\left(\mathrm{Ca}_{5} \mathrm{Si}_{2} \mathrm{O}_{7}\left(\mathrm{CO}_{3}\right) 2\right.\right.$, PDF\#73-2117) and sodium aluminium silicate carbonate $\left(\mathrm{Na}_{8} \mathrm{Al}_{6} \mathrm{Si}_{6} \mathrm{O}_{24} \mathrm{CO}_{3}, \mathrm{PDF} 000-024-\right.$ 1045). The stronger activation evidently determined some dissolution of the glass (in turn favouring the incorporation of $\mathrm{Ca}^{2+}, \mathrm{Al}^{3+}$ and $\mathrm{Si}^{4+}$ in carbonates), but it did not lead to any practical formation of non-carbonate phases.

Significant changes occurred in foams made with addition of $10 \mathrm{wt} \%$ soda-lime glass (Figure 4, C/D groups). This addition had been conceived to yield stronger foams, in the green state, by keeping a low molarity of activating solution $(1 \mathrm{M} \mathrm{NaOH})$. The low molarity did not cause the formation of C-S-H compounds (previously observed with waste glass/soda lime mixtures (Monich et al., 2018), but turned the newly formed phases from being sodium based to being calcium based. Calcium carbonate $\left(\mathrm{CaCO}_{3^{\prime}}\right.$ PDF\#86-2339) was clearly detected. The remaining peak is consistent with the presence of traces of the alumino-silicate zeolite gismondine ( $\left.\mathrm{CaAl}_{2} \mathrm{Si}_{2} \mathrm{O}_{8} \cdot 4 \mathrm{H}_{2} \mathrm{O}, \mathrm{PDF} 20-0452\right)$. Gismondine is interesting, being found in geopolymers from granulated blast furnace slag (Zhang, Zhao, Li, \& Xu, 2008), i.e. in products from very strong alkali activation.

The different formulations had some impacts after firing. The XRD patterns (Figure 5) of foams fired at $900^{\circ} \mathrm{C}$ showed signals consistent with those of labradorite $\left(\mathrm{Ca}_{0.64} \mathrm{Na}_{0.35}\left(\mathrm{Al}_{1.63} \mathrm{Si}_{2.37} \mathrm{O}_{8}\right)\right.$, PDF\#83-1371) and gehlenite $\left(\mathrm{Ca}_{2}\left(\mathrm{Al}(\mathrm{AlSi}) \mathrm{O}_{7}\right), \mathrm{PDF} \# 74-1607\right)$. Labradorite and gehlenite have already been previously detected in glass-ceramics made with plasma vitrified MSWI fly ashes (Bernardo et al., 2011). We cannot exclude the presence also of an Al-

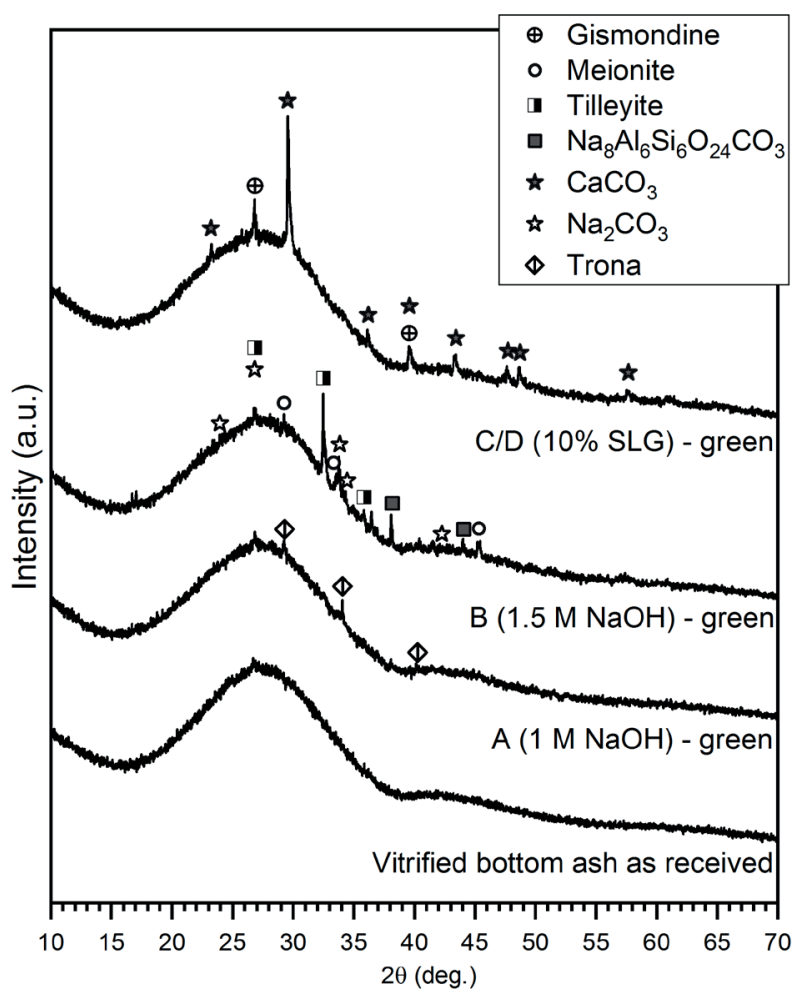

FIGURE 4: High resolution XRD patterns of vitrified bottom ash and not fired foams. rich pyroxene (augite, $\mathrm{CaMg}_{0.7} \mathrm{Al}_{0.6} \mathrm{Si}_{1.7} \mathrm{O}_{6}$, PDF\#78-1392). Pyroxene solid solutions are quite typical in waste-derived glass-ceramics (Park, Moon, \& Heo, 2003), as well as plagioclase and melilite solid solutions (comprising labradorite and gehlenite, respectively).

Figure 5 also indicates that the increase of molarity of the alkaline solution and the introduction of soda-lime glass had a 'symmetrical' effect on the crystallization: compared to ' $A$ ' foams, both foams from stronger activation (' $B$ ' type) and from glass addition (' $C$ ' type) exhibited more marked peaks. However, it may be seen that in the first case all peaks became more intense; in the second, on the contrary, gehlenite had a more significant increase.

The enhanced crystallization is reasonably due to the increase of overall alkali content in both groups B and C, which may have lowered the apparent activation energy for crystal growth, as already observed for alkali rich glasses (Watanabe, Hashimoto, Hayashi, \& Nagata, 2008)). The enhancement of crystallization was found at $900^{\circ} \mathrm{C}$; firing below the crystallization temperature of vitrified bottom ash (at $800^{\circ} \mathrm{C}$, group D) led simply to fully amorphous foams.

The glass-ceramic foams presented porosity higher than 58 vol\%, mainly open, as shown by Table 3 . Table 3 also indicates that the increase of molarity from $1 \mathrm{M}$ to $1.5 \mathrm{M}$ enabled the increase of almost $10 \%$ in porosity. The reason probably lies on the fact that the more "gelified" suspension (group B, as shown in Figure 4) could prevent more efficiently the collapse of the bubbles entrapped after foaming. Due to their high porosity, the foams from group B could be potentially applied as thermal or acoustic insulators in buildings. Regarding the mechanical properties,

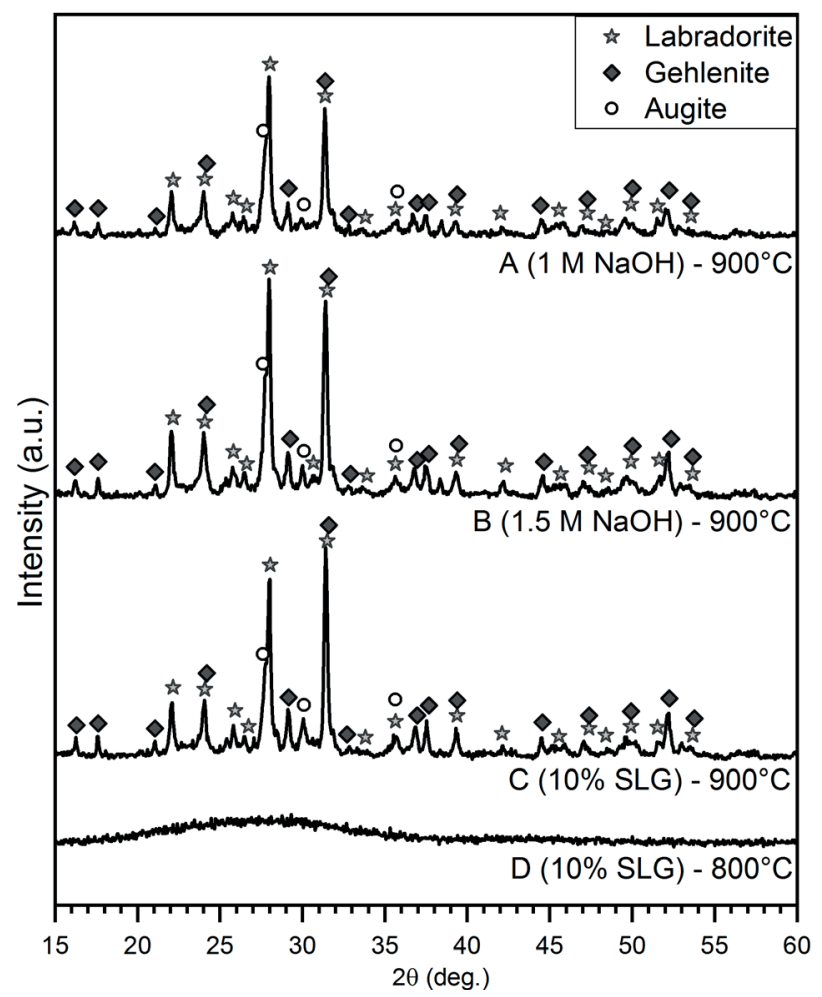

FIGURE 5: XRD patterns of the fired vitrified bottom ash derived foams. 
the compressive strength reached a maximum of $8.1 \mathrm{MPa}$ for foams made with a stronger alkaline solution (group B). This value is well above the typical crushing strength for commercial glass foams, which lies between 0.4 and 6 MPa (Scarinci, Brusatin, \& Bernardo, 2006); in addition, the strength-to-density ratio compares well with that of commercial foams (e.g. alumina foams with the similar density hardly exceed $8 \mathrm{MPa}$ ) (CES EduPack, 2018).

Foams made with soda-lime glass (groups C and D), on the other hand, did not present an increase of porosity. In addition, the increase in firing temperature from $800^{\circ} \mathrm{C}$ to $900^{\circ} \mathrm{C}$, enabling crystallization, determined $38 \%$ increase in the strength of the foams.

The micrographs of the porous materials are shown in Figure 6 . As already indicated by Table 3 , the foams present high porosity, mainly open. The increase in the molarity of the alkaline solution from $1 \mathrm{M}$ (group A) to $1.5 \mathrm{M}$ (group $\mathrm{B}$ ) decreased substantially the pore size. The decrease in pore size could be one of the reasons lying behind the increase in compressive strength in foams from groups $B$, despite presenting a higher porosity. As already observed in another study, foams with smaller macro-pore size presented higher compressive strength than foams with a larger macro-pore size up to a certain level of porosity (Liu, 1997).
Regarding the foams made with addition of soda-lime glass (groups $C$ and D), it may be observed the influence of the firing temperature on the pore size distribution: foams fired at $800^{\circ} \mathrm{C}$ (group D) present a larger pore size than foams fired at $900^{\circ} \mathrm{C}$ (group C). As the foams were still amorphous at $800^{\circ} \mathrm{C}$ (Figure 5), the softened glass may have contributed to reshape the pores during firing, before crystallization. The precipitation of crystals increased then the viscosity of the softened glass, which prevented a further reshaping of pores at higher temperatures (Rincón, Giacomello, Pasetto, \& Bernardo, 2017).

As vitrified bottom ash is originated from waste, it is essential to perform leaching test on the samples, in order to verify if the leaching of heavy metals is within the regulation. Table 4 shows that the vitrification of MSWI bottom ash effectively yielded a safe material with very low leaching of heavy metals. Concerning the glass-ceramic foams made with only vitrified bottom ash (groups $A$ and B), the leaching of heavy metals was below the limit values for inert and non-hazardous waste. On the other hand, due to a high leaching of $\mathrm{Sb}$, foams made with soda-lime glass (groups $\mathrm{C}$ and D) could only be accepted as non-hazardous waste.

The increase in the alkalinity of the residual glass, with
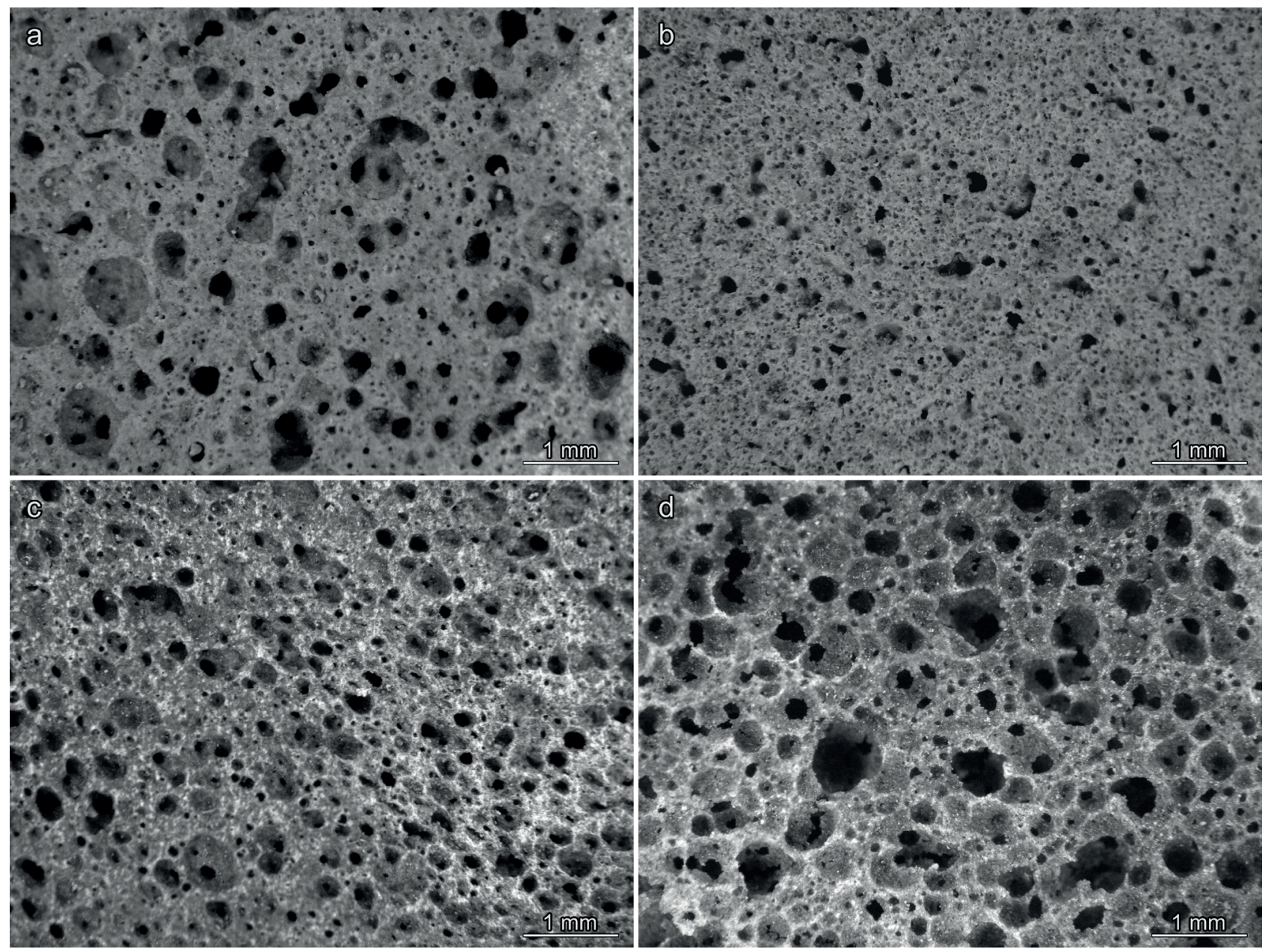

FIGURE 6: Micrographs of the four types of porous glass-ceramics developed: a) group A, $1 \mathrm{M} \mathrm{NaOH}$; b) group B, $1.5 \mathrm{M} \mathrm{NaOH}$; c) group C, $10 \%$ SGL fired at $900^{\circ} \mathrm{C}$; d) group D, $10 \%$ SGL fired at $800^{\circ} \mathrm{C}$. 
TABLE 3: Porosity and mechanical properties of the four groups of porous materials produced.

\begin{tabular}{|c|c|c|c|c|}
\hline Group of samples & A & B & C & D \\
\hline Activation & $1 \mathrm{M} \mathrm{NaOH}$ & $1.5 \mathrm{M} \mathrm{NaOH}$ & $1 \mathrm{M} \mathrm{NaOH}$ & $1 \mathrm{M} \mathrm{NaOH}$ \\
\hline Soda-lime glass (\%) & - & - & $10 \%$ & $10 \%$ \\
\hline Sintering Temperature $\left({ }^{\circ} \mathrm{C}\right)$ & 900 & 900 & 900 & 800 \\
\hline \multicolumn{5}{|l|}{ Density determinations } \\
\hline$\rho_{\text {geom }}\left(\mathrm{g} / \mathrm{cm}^{3}\right)$ & $1.04 \pm 0.08$ & $0.85 \pm 0.04$ & $1.03 \pm 0.03$ & $1.07 \pm 0.09$ \\
\hline$\rho_{\text {apparent }}\left(\mathrm{g} / \mathrm{cm}^{3}\right)$ & $2.28 \pm 0.01$ & $2.59 \pm 0.03$ & $2.45 \pm 0.04$ & $2.54 \pm 0.04$ \\
\hline$\rho_{\text {true }}\left(\mathrm{g} / \mathrm{cm}^{3}\right)$ & $2.52 \pm 0.00$ & $2.62 \pm 0.00$ & $2.53 \pm 0.01$ & $2.57 \pm 0.00$ \\
\hline$\rho_{\text {rel }}$ & 0.412 & 0.326 & 0.407 & 0.414 \\
\hline \multicolumn{5}{|l|}{ Porosity distribution } \\
\hline Total porosity, P (\%) & 58.8 & 67.4 & 59.3 & 58.6 \\
\hline Open porosity, OP (\%) & 54.4 & 67.0 & 58 & 58.1 \\
\hline Closed porosity, CP (\%) & 4.4 & 0.4 & 1.3 & 0.5 \\
\hline \multicolumn{5}{|l|}{ Strength determinations } \\
\hline$\sigma_{\text {comp }}(\mathrm{MPa})$ & $7.0 \pm 2.7$ & $8.1 \pm 1.1$ & $7.3 \pm 1.8$ & $5.3 \pm 2.0$ \\
\hline
\end{tabular}

TABLE 4: Results of the leaching test of vitrified bottom ash and of the four groups of foams (mg/kg) [*: above limit].

\begin{tabular}{|c|c|c|c|c|c|c|c|}
\hline & \multicolumn{2}{|c|}{ Limits (Directive 2003/33/EC, 2003) } & \multirow{2}{*}{ VBA } & \multirow{2}{*}{ A } & \multirow{2}{*}{ B } & \multirow{2}{*}{ C } & \multirow{2}{*}{ D } \\
\hline & Inert waste & Non-hazardous waste & & & & & \\
\hline As & 0.5 & 2 & 0.0076 & $<0.0049$ & $<0.0049$ & $<0.0049$ & $<0.0049$ \\
\hline $\mathrm{Ba}$ & 20 & 100 & 0.0054 & 0.0354 & 0.0696 & 0.0041 & 0.0061 \\
\hline $\mathrm{Cd}$ & 0.04 & 1 & $<0.0002$ & 0.0004 & $<0.0002$ & $<0.0002$ & $<0.0002$ \\
\hline Cr total & 0.5 & 10 & 0.0066 & 0.0072 & 0.0021 & 0.0020 & 0.0146 \\
\hline $\mathrm{Cu}$ & 2 & 50 & 0.0219 & 0.0128 & 0.0024 & 0.0003 & 0.002 \\
\hline $\mathrm{Hg}$ & 0.01 & 0.2 & $<0.0004$ & $<0.0004$ & $<0.0004$ & 0.0023 & 0.0015 \\
\hline Mo & 0.5 & 10 & 0.0184 & $<0.0033$ & $<0.0033$ & $<0.0033$ & $<0.0033$ \\
\hline $\mathrm{Ni}$ & 0.4 & 10 & 0.0017 & 0.0042 & $<0.0014$ & $<0.0014$ & $<0.0014$ \\
\hline $\mathrm{Pb}$ & 0.5 & 10 & 0.0068 & 0.0111 & 0.0072 & $<0.0047$ & $<0.0047$ \\
\hline $\mathrm{Sb}$ & 0.06 & 0.7 & 0.0339 & 0.0151 & 0.0320 & $0.3518^{*}$ & $0.2316^{\star}$ \\
\hline Se & 0.1 & 0.5 & $<0.0122$ & 0.0163 & 0.0221 & $<0.0122$ & $<0.0122$ \\
\hline $\mathrm{Zn}$ & 4 & 50 & $<0.0203$ & $<0.0203$ & $<0.0203$ & $<0.0203$ & $<0.0203$ \\
\hline \multicolumn{3}{|r|}{ Final pH } & 7.8 & 8.0 & 8.0 & 7.6 & 7.5 \\
\hline
\end{tabular}

the addition of soda-lime glass, may have favoured its dissolution (Monich et al., 2018; P. Pisciella, Crisucci, Karamanov, \& Pelino, 2001). It must be observed, however, that the leaching tests were applied on glass foam fragments, i.e. on samples with huge specific surface. The conditions of chemical attack, as well the reference limits (intended for materials to be disposed in landfills), were probably excessive.

\section{CONCLUSIONS}

We may conclude that:

- The technique based on alkali activation, gelation, foaming and sintering could be applied to produce porous and strong glass-ceramics made with vitrified bottom ash, with limited costs (considering the limited alkalinity of activating solutions and low firing temperatures);

- The valorisation of vitrified bottom ash into porous and strong glass-ceramics by an economic process has the potential to produce potential marketable products.
This could help to decrease the high costs of vitrification;

- The hardening of the suspension originates mainly from the formation of carbonates;

- The increase in molarity from 1 to $1.5 \mathrm{M}$ produced stronger foams with higher porosity and smaller pore size;

- The introduction of soda-lime glass allowed the achievement of comparable compressive strength (at $900^{\circ} \mathrm{C}$ ), with a reduced molarity of activating solution; however, this was accompanied by some degradation of the stabilization of pollutants.

'Declarations of interest: none'.

\section{ACKNOWLEDGEMENTS}

The research leading to these results has received funding from the European Union's Horizon 2020 research and innovation programme under the Marie Sklodowska-Curie 
grant agreements No. 721185 "NEW-MINE" (EU Training Network for Resource Recovery through Enhanced Landfill Mining; website: http://new-mine.eu/). The Erasmus+ traineeships program (funding Fulden Dogrul's mobility) is also acknowledged.

\section{REFERENCES}

Bassani, M., Santagata, E., Baglieri, O., Ferraris, M., Salvo, M., \& Ventrella, A. (2009). Use of vitrified bottom ashes of municipal solid waste incinerators in bituminous mixtures in substitution of natural sands. Advances in Applied Ceramics, 108(1), 33-43. http://doi. org/10.1179/174367608X364285

Bernardo, E. (2008). Fast sinter-crystallization of a glass from waste materials. Journal of Non-Crystalline Solids, 354(29), 3486-3490. http://doi.org/10.1016/j.jnoncrysol.2008.03.021

Bernardo, E., Dattoli, A., Bonomo, E., Esposito, L., Rambaldi, E., \& Tucci, A. (2011). Application of an industrial waste glass in "glass-ceramic stoneware." International Journal of Applied Ceramic Technology, 8(5), 1153-1162. http://doi.org/10.1111/ j.1744-7402.2010.02550.x

CES EduPack 2018 software package - https://grantadesign.com (2018)

Colombo, P., Brusatin, G., Bernardo, E., \& Scarinci, G. (2003). Inertization and reuse of waste materials by vitrification and fabrication of glass-based products. Current Opinion in Solid State and Materials Science, 7(3), 225-239. http://doi.org/10.1016/j.cossms.2003.08.002

Cucchiella, F., D’Adamo, I., \& Gastaldi, M. (2017). Sustainable waste management: Waste to energy plant as an alternative to landfill. Energy Conversion and Management, 131, 18-31. http://doi. org/10.1016/j.enconman.2016.11.012

Directive 2003/33/EC. (2003). Official Journal of the European Communities.

Elsayed, H., Romero, A. R., Ferroni, L., Gardin, C., Zavan, B., \& Bernardo, E. (2017). Bioactive glass-ceramic scaffolds from novel "inorganic gel casting" and sinter-crystallization. Materials, 10(2). http://doi. org/10.3390/ma10020171

Garcia-Lodeiro, I., Aparicio-Rebollo, E., Fernández-Jimenez, A., \& Palomo, A. (2016). Effect of calcium on the alkaline activation of aluminosilicate glass. Ceramics International, 42(6), 7697-7707. http:// doi.org/10.1016/j.ceramint.2016.01.184

He, P. J., Pu, H. X., Shao, L. M., \& Zhang, H. (2017). Impact of co-landfill proportion of bottom ash and municipal solid waste composition on the leachate characteristics during the acidogenesis phase. Waste Management, 69, 232-241. http://doi.org/10.1016/j.wasman.2017.08.021

Höland, W., \& Beall, G. H. (2012). Glass-Ceramic Technology. Hoboken, NJ, USA: John Wiley \& Sons, Inc.

Hoornweg, D., \& Bhada-Tata, P. (2012). What a waste: A global review of solid waste management. The World Bank (Vol. 15). Washington. http://doi.org/10.1111/febs. 13058

Joseph, A., Snellings, R., Van den Heede, P., Matthys, S., \& De Belie, N. (2018). The Use of Municipal Solid Waste Incineration Ash in Various Building Materials: A Belgian Point of View. Materials, 11(1), 141. http://doi.org/10.3390/ma11010141

Liu, D. M. (1997). Influence of porosity and pore size on the compressive strength of porous hydroxyapatite ceramic. Ceramics International, 23(2), 135-139. http://doi.org/10.1016/S02728842(96)00009-0
Monich, P. R., Romero, A. R., Höllen, D., \& Bernardo, E. (2018). Porous glass-ceramics from alkali activation and sinter-crystallization of mixtures of waste glass and residues from plasma processing of municipal solid waste. Journal of Cleaner Production, 188, 871878. http://doi.org/10.1016/j.jclepro.2018.03.167

Norm EN 12457-4. (2002).

Park, Y. J., Moon, S. O., \& Heo, J. (2003). Crystalline phase control of glass ceramics obtained from sewage sludge fly ash. Ceramics International, 29(2), 223-227. http://doi.org/10.1016/S02728842(02)00109-8

Pisciella, P., Crisucci, S., Karamanov, A., \& Pelino, M. (2001). Chemical durability of glasses obtained by vitrification of industrial wastes. Waste Management, 21(1), 1-9. http://doi.org/10.1016/S0956053X(00)00077-5

Pisciella, P., \& Pelino, M. (2005). FTIR spectroscopy investigation of the crystallisation process in an iron rich glass. Journal of the European Ceramic Society, 25(11), 1855-1861. http://doi.org/10.1016/j. jeurceramsoc.2004.06.012

Rincón, A., Desideri, D., \& Bernardo, E. (2018). Functional glass-ceramic foams from 'inorganic gel casting' and sintering of glass/slag mixtures. Journal of Cleaner Production, 187, 250-256. http://doi. org/10.1016/j.jclepro.2018.03.065

Rincón, A., Giacomello, G., Pasetto, M., \& Bernardo, E. (2017). Novel 'inorganic gel casting' process for the manufacturing of glass foams. Journal of the European Ceramic Society, 37(5), 2227-2234. http://doi.org/10.1016/j.jeurceramsoc.2017.01.012

Rincón, A., Marangoni, M., Cetin, S., \& Bernardo, E. (2016). Recycling of inorganic waste in monolithic and cellular glass-based materials for structural and functional applications. Journal of Chemical Technology and Biotechnology, 91(7), 1946-1961. http://doi. org/10.1002/jctb.4982

Rincon Romero, A., Salvo, M., \& Bernardo, E. (2018). Up-cycling of vitrified bottom ash from MSWI into glass-ceramic foams by means of 'inorganic gel casting' and sinter-crystallization. Construction and Building Materials, 192, 133-140. http://doi.org/10.1016/j.conbuildmat.2018.10.135

Sabbas, T., Polettini, A., Pomi, R., Astrup, T., Hjelmar, O., Mostbauer, P., ... Lechner, P. (2003). Management of municipal solid waste incineration residues. Waste Management, 23(1), 61-88. http://doi. org/10.1016/S0956-053X(02)00161-7

Scarinci, G., Brusatin, G., \& Bernardo, E. (2006). Glass Foams. Cellular Ceramics: Structure, Manufacturing, Properties and Applications, 158-176. http://doi.org/10.1002/3527606696.ch2g

Silva, R. V., de Brito, J., Lynn, C. J., \& Dhir, R. K. (2017). Use of municipal solid waste incineration bottom ashes in alkali-activated materials, ceramics and granular applications: A review. Waste Management, 68, 207-220. http://doi.org/10.1016/j.wasman.2017.06.043

Silva, R. V., de Brito, J., Lynn, C. J., \& Dhir, R. K. (2019). Environmental impacts of the use of bottom ashes from municipal solid waste incineration: A review. Resources, Conservation and Recycling, 140(June 2018), 23-35. http://doi.org/10.1016/j.resconrec.2018.09.011

Tillman, D. A., Vick, K. M., \& Rossi, A. J. (1989). Incineration of Municipal and Hazardous Solid Wastes. Incineration of Municipal and Hazardous Solid Wastes (Academic P). Elsevier. http://doi. org/10.1016/B978-0-12-691245-6.X5001-9

Watanabe, T., Hashimoto, H., Hayashi, M., \& Nagata, K. (2008). Effect of Alkali Oxides on Crystallization in $\mathrm{CaO}-\mathrm{SiO} 2-\mathrm{CaF} 2$ Glasses. ISIJ International, 48(7), 925-933. http://doi.org/10.2355/isijinternational.48.925

Zhang, Y. J., Zhao, Y. L., Li, H. H., \& Xu, D. L. (2008). Structure characterization of hydration products generated by alkaline activation of granulated blast furnace slag. Journal of Materials Science, 43(22), 7141-7147. http://doi.org/10.1007/s10853-008-3028-9 